Article

\title{
The Sustainability of Businesses in Kigali, Rwanda: An Analysis of the Barriers Faced by Women Entrepreneurs
}

\author{
Simon Nsengimana, Robertson K. Tengeh * (D) and Chux Gervase Iwu \\ Department of Entrepreneurship and Business Management, Faculty of Business and Management Sciences, \\ Cape Peninsula University of Technology, Cape Town 8000, South Africa; nsengasimon@yahoo.fr (S.N.); \\ iwuc@cput.ac.za (C.G.I.) \\ * Correspondence: tengehr@cput.ac.za; Tel.: +27-21-460-3450; Fax: +27-86-778-0394
}

Received: 5 July 2017; Accepted: 1 August 2017; Published: 4 August 2017

\begin{abstract}
Given their sheer number and "motherly instincts" one would expect that the effective participation of women in entrepreneurial activities will offer a far reaching impact on the economy, yet their contribution is barely apparent in a number of developing countries. Assuming that women are unique, this paper sought to determine the specific barriers faced by women entrepreneurs in doing business in Kigali. Anchored on the quantitative approach, the requisite data was obtained from 398 women entrepreneurs operating formal and informal business in the city of Kigali using structured self-administered questionnaires. Aiming for descriptive statistics, the data collected was analysed using the latest version of Statistical Package for the Social Sciences (SPSS) software. The results suggest that women entrepreneurs face a number of challenges in running their businesses in Kigali. These challenges are not limited to among others, the lack of collateral to obtain loans, high taxes, a lack of information technology skills and access, high interest rates, high transport costs, a lack of entrepreneurial skills, but are also compounded by cultural and psychological factors. Therefore, our view is that, it will take time and the combined efforts of women entrepreneurs themselves, society, their families, government, researchers and other stakeholders to overcome these challenges.
\end{abstract}

Keywords: sustainability; entrepreneurship; women entrepreneurship; developing economy; emerging market; formal and informal business

\section{Introduction}

Despite the fact that entrepreneurship has been acknowledged as the backbone of many economies in both developed and developing countries, the contributions of women are yet to be fully recognised. Women constitute a significant portion of most economies but at the same time, they are notably marginalised and often on the receiving end of patriarchal prejudices. A common agenda in most development agendas of governments is women. This is not surprising especially considering that most societies treat women as second class citizens [1]; the businesses set up by women do not always do as well as the men in terms of growth and profitability [2] and women struggle more to access funding opportunities $[3,4]$. Interestingly, researchers such as $[1,5-7]$ have confirmed that women can run businesses, support their families and community and contribute to economic growth. This goes to show that not significantly providing for women to participate in entrepreneurship is a loss to the nation and society.

Rwanda women also confront enormous challenges in comparison to their male counterparts. Women make up almost $52 \%$ of the population in Rwanda, but are underrepresented in business for reasons of custom, culture, belief, and religion [5]. In Rwandan society, women are regarded as well 
suited to domestic activities such as raising children, looking after domestic animals, food production, and cooking. Typically, women are considered to be too weak to carry out entrepreneurial activities [5]. Nevertheless, only few women in Rwanda have broken this barrier and started their own enterprises. In Kigali for instance, the political and economic capital of Rwanda, women entrepreneurs represent $43.2 \%$ of all entrepreneurial activities [5,8,9]. In rural areas, however, female entrepreneurs are comparatively less active in business than their male counterparts [10]. Although significant changes have taken place in terms of women entrepreneurship in Rwanda, the challenges that women face in this regard are not well known and there appears to be no research studies on the subject. A study such as this will help in highlighting the barriers faced by women entrepreneurs in doing business in Kigali, as well as possibly indicate ways to avert the problems.

The rest of the paper is organised as follows. The next section reviews literature, and drawing from their findings to offer some substance to our study. Thereafter, the methodological steps used in carrying out this study are provided. What follows after this is a comprehensive description and discussion of the findings. The study concludes by reiterating the key findings and at the same time offering sound implications both for theory and practice.

\section{Literature Review}

Several definitions have been offered for women entrepreneurship. Schumpeter's [11] characterisation of women in entrepreneurship suggests the recognition of women as equal partners in an enterprise either in terms of equity contributions or the skills, knowledge and abilities they bring. This characterisation seems to have led to the definitions of women entrepreneurs as we know them today. For instance, the government of India defines a woman entrepreneur in terms of the percentage of ownership of a business [12]. Essentially, a woman who possesses more than $50 \%$ of shares in a particular business is deemed an entrepreneur. Other authors refer to the role women play in starting a new venture or setting strategy, simply adding a gender marker to the notion of the entrepreneur. In this case, [13] are of the view that a woman who applies experience, skills, and knowledge to grow a business or generate a venture opportunity qualifies to be called an entrepreneur. Begum [14] considers a woman entrepreneur as one who is either conventional or rudimentary in her approach whether in a highly innovative setting or a domestic venture, but primarily with authority. So basically, a woman entrepreneur is one who initiates, organises, and runs a business enterprise.

\subsection{Rwanda Women Entrepreneurs and Their Importance}

During the colonial era, Rwandan women made little contribution to politics or the economy; they did not have the right to own land and properties $[15,16]$. Also, during the colonial era, opportunities were skewed in favor of Rwandan men. For example, women were not given the opportunity to receive education and when a slight opportunity showed, their studies were limited to teaching, nursing, and social work. Science and technical courses were for boys. Early after independence, the National University of Rwanda (NUR) started with only male students.

However, noticeable contributions have emerged since the genocide of 1994. As [16] notes, Rwandan women have asserted themselves in entrepreneurship, government, and politics, as well as in attempts to reform laws that discouraged gender equality so that many more women can participate in business enterprises. Despite post-colonial efforts to promote gender equality, women are still underrepresented in most of all spheres of Rwandan life [16].

Both men and women entrepreneurs contribute to a country's economic growth and social life. However, women entrepreneurs' income contributes more to the family and immediate community than that of male entrepreneurs [7,17]. Supporting women's entrepreneurial activities in a developing country is a means to help eradicate poverty and malnutrition, and at the same time improving public health and productivity, and reducing dependence on external aid [18]. In the past two decades, Rwandan women have launched a considerable number of enterprises; they have made a strong contribution to socio-economic recovery in the aftermath of the genocide, to the extent that 
government views them as a critical stakeholder [7,19]. Interestingly, gender continues to be implicated as a deterrent to female entrepreneurs $[15,20]$.

According to [8], female entrepreneurship accounts for $42 \%$ of enterprises countrywide, and $58 \%$ of informal businesses. Women entrepreneurs are concentrated mostly in retail $(82 \%)$, with some in service (16-17\%), and manufacturing (1-2\%). They contribute 30\% of the GDP [8]. According to [21], most women-owned enterprises are informal, which explains why their contribution to GDP is relatively low. The Rwandan government reports a total of 142,029 businesses, of which 101,665 are male owned (71.58\%), 38,017 female (26, 77\%), and 2347 with no apparent sex identity (NS) $(1.65 \%)$. Table 1 depicts the distribution of sole proprietor establishments in Rwanda by gender and size.

Table 1. Distribution of sole proprietor establishments by sex of owner and size.

\begin{tabular}{ccccc}
\hline \multirow{2}{*}{ Size } & \multicolumn{4}{c}{ Sex of Owner } \\
\cline { 2 - 5 } & Total & Male & Female & NS \\
\hline Total & 142,029 & 101,665 & 38,017 & 2347 \\
Micro (1-3) & 135,386 & 96,987 & 36,169 & 2230 \\
Small (4-30) & 6469 & 4538 & 1817 & 114 \\
Medium (31-100) & 133 & 104 & 27 & 2 \\
Large (100+) & 41 & 36 & 4 & 1 \\
\hline
\end{tabular}

Source: National Institute of Statistics of Rwanda (2015:55).

\subsection{Challenges Women Entrepreneurs Face in Doing Business in Kigali}

Female entrepreneurs face similar challenges to male entrepreneurs. However, women face extra specific challenges because of societal stereotypes [22-24]. These include inadequate access to finance, lack of collateral, high taxes, high interest rates, a lack of business management skills in the industry in which they are operating, a lack of viable physical facility, which is why a considerable number of women run their business from home; difficulties with reaching a market for their products, especially those from rural areas; low consumer purchase capacity. Add to these the fact that they are operating within a society which encourages discrimination and inequality [20].

Entrepreneurial education and training are critical tools for female entrepreneurs to successfully manage a business, not least because they update entrepreneurs on current and future business trends $[25,26]$. Education, skills and the experience in industry with which an entrepreneur starts a business influence its chances of success [27]. It has also been suggested that networks facilitating the flow of information from various sources could be a key factor in the success of women's entrepreneurial ventures [28]. A lack of own transport could also negatively impact a woman's business venture. As the [29] puts it, often spouses discourage the women from travelling alone and even using public transport as it may expose the women to sexual harrasment and other prejudices.

Women entrepreneurs are anxious about the many requirements from government and local administrations for running a business; every single document they have to pay for they regard as an unnecessary expense [30]. According to [31], in India many officials delay the licences and other documents needed for business by women entrepreneurs in order to extract a bribe from them. This culture of corruption costs time and money and discourages would-be women entrepreneurs. According to the [32], corruption in both public and private sectors is considerably lower in Rwanda than elsewhere in the region: Rwanda 4.35\%; Burundi 19.72\%; Uganda 23.57\%; Tanzania 51.11\%; and Kenya $73.8 \%$. Sex is used as a means to curry favors from Rwandan public and private sectors, with women being asked for sex in order to get a job or promotion, or to obtain a business opportunity. Refusing corruption is regarded as losing an opportunity [33]. According to the [34], only $16 \%$ or 350,000 households have access to electricity. The cost of electricity is very high: twice the cost in Uganda and Tanzania, and four times that in South Africa and India. Rwanda does not have railways, and so road transport is generally used. The cost of transportation is high locally and extremely high 
for import and export. The high cost of transport affects the competitiveness and growth of women's enterprises [32].

\section{Materials and Methods}

\subsection{Method}

This study used a quantitative method. The quantitative method is used to objectively measure attitudes, behaviours and opinions in social and business fields [35]. Sukamolson [35] argues that the quantitative method comprises a high degree of reliability, generalisable results, correlation between variables and effects, and provides statistics that are easy to interpret and update. The quantitative method was deemed appropriate to finding out, on a statistical level, more about the challenges women entrepreneurs in Kigali face in business, and quantifying them according to their magnitude.

Maree [36] observes that there are different methods of performing quantitative research, including descriptive research, correlational, developmental design, observational studies, and survey research. This study used a quantitative descriptive design and a survey questionnaire technique to collect data from women entrepreneurs in Kigali. Statistical Package for the Social Sciences (SPSS) was used to analyse data displayed statistically in table form.

The data analysis was done using the latest version of the Statistical Package for the Social Sciences (SPSS) software. Anchored on descriptive statistics, the analysis sought to present the results in the form of frequencies, percentages, and means.

\subsection{Sample}

Since the exact number of women entrepreneurs in City of Kigali is unknown [20,33,37], the Roasoft sample size calculator was used on a proposed population size of 20,000, with a confidence level of $95 \%$ ( $5 \%$ error may be tolerated) and $50 \%$ response distribution [38]. The Roasoft sample size calculator recommended a sample of 377. A purposive sampling method was used to select women entrepreneurs in City of Kigali to participate in the study. Purposive sampling allows a researcher the freedom to choose the respondents [39] who in his view might provide credible information with little bias and error and a high degree of reliability and validity [40]. Purposive sampling was an appropriate technique to approach respondents especially hawkers in Kigali.

The target population for this study comprised women entrepreneurs in the formal and informal sectors in the City of Kigali. These women were active in various categories of business, including services; manufacturing, agriculture, wholesale, retail and construction. They had to be 18 years and older because this is the legal working age [41]. They had to be Rwandan citizens residing in the city and involved in the formal or informal sector; and their business had to be at least 6 months old. The recommended minimum sample size was 377, but 398 questionnaires were collected. The larger the sample, the better the validity and reliability of the results it yields [42].

\subsection{Questionnaire}

This study used opinion and attribute variables in the questionnaire: seeking women entrepreneurs' opinion in line with the challenges they face in business in Kigali, and collecting information about the profiles of respondents and their businesses. The questionnaire had two categories of questions: those that gathered biographical data and those that asked for ratings using a Likert scale. According to [36,39] questions and answers involving evaluation and opinion usually use a Likert-style rating scale, where a respondent is asked to rate his or her level of response to a statement. According to $[25,36]$, in closed-ended questions, the respondents select one or more responses from a list provided, while with open-ended questions there is a reserved space where the respondents write their response. Our questionnaire used biographical questions including questions inviting response on a 5-point Likert scale. The questionnaire contained 6 sections (A, B, C, D, E, and F), as follows: 
Section A requested demographic information from the women entrepreneurs, such as marital status, level of education, and age group. The aim of section A was to provide knowledge of the population and determine whether they qualified to participate in the survey; it also helped the researchers to identify which categories of women were more active or less active in business; Section B gathered information regarding the sector in which the business operates; the age of the business; the source of start-up capital and the amount; number of employees; sales; and business registration. The aim of section B was to identify the business sector as well as categories of business in terms of micro enterprises, small enterprises, medium enterprises, and large enterprises; Section $C$ solicited information about specific constraints that women entrepreneurs experienced in running businesses in Kigali.

Besides Sections A and B that focused on categorical variables, the rest (Sections C-E) of the items on the questionnaire were measured along a 5-point Likert scale (ordinal). The scale ranged from 1 (Strongly disagree) to 5 (Strongly agree).

\section{Findings and Discussion}

398 subjects participated in this study. Out of this number, the majority of the respondents, $314(79.1 \%)$ were married; 51 (12.8\%) were single; and very few, $2(0.5 \%)$ were divorced. The results show that the subjects comprised mostly married women. Could this be that married women entrepreneurs had more financial power than women in other categories ( $21 \%$ in total), or better supported by spouses? An almost similar study [4] also had more married subjects than unmarried ones. The findings also indicate that the level of education of the majority $(354 / 87.3 \%)$ of the subjects was limited to formation (Formation in this study and in the Rwandan context is the career-oriented training given to a person who may or may not have finished primary school but did not have the opportunity to pursue secondary education.), primary, and secondary schooling. It might be that this group of women entrepreneurs resorted to entrepreneurship because it was difficult for them to secure employment. The 46 women $(11.7 \%)$ who were educated to Diploma and Bachelor degree level might have enrolled in business either because they had entrepreneurial ambitions or because they also failed to find a job in the public or private sector. The low proportion of educated women entrepreneurs in Kigali is in line with the [43] claim that educated women began entrepreneurial activities because of a lack of employment opportunities in the labour market. In this study, very few respondents $(4 / 1 \%)$, had no formal education. The age group of the participants ranged from 18 to 64 years, with a mean age of 40 and a majority of 239 (60.2\%) being in the age group of 29-43 years old. Interestingly, there is a relationship between the age of the respondents and their participation in entrepreneurship. It appears more women participate in entrepreneurship as they grow to maturity and become less active as they advance in age. According to these findings, the age group 18-48 $(305,77 \%)$ are more likely to engage in entrepreneurial activities than the age group of 49-64 years old and over $(92,23.3 \%)$. This is not surprising as people in the age group of $18-48$ years are more energetic and active and can better withstand the demands of running a business than their older counterparts. It is gratifying to see young people in business, as this will ensure that more young people are self-reliant.

From the findings in the category of business profile, we note that most respondents $(64.6 \%)$ run retail businesses, of which the majority $(67.8 \%)$ are in service industry, mostly clothing. Most respondents have been in business for a period of 6 to 10 years and many of them $(39.7 \%)$ received their start-up capital from their husbands. The vast majority of the women entrepreneurs (92.9\%) started their business with capital of less than RwF 500,000. Most respondents (79.3\%) run their business with 1 to 3 employees and the majority of them $(87.3 \%)$ have an annual income in the range of RwF 1,000,000-3,000,000, qualifying them as micro-enterprises. A large percentage of the women entrepreneurs in this study $(71.3 \%)$ had their businesses legally registered with the Rwanda Development Board and the Rwanda Cooperative Agency. The survey results in terms of the specific 
barriers facing women entrepreneurs in Kigali are depicted in Table 2. Descriptive statistics were used while mean values were derived.

Table 2. Challenges facing women entrepreneurs in Kigali.

\begin{tabular}{|c|c|c|c|c|c|}
\hline \multicolumn{6}{|c|}{ Descriptive Statistics } \\
\hline Collateral to obtain loan & 397 & 2 & 5 & 4.26 & 0.608 \\
\hline Lack of information technology skills (e.g., internet) & 397 & 2 & 5 & 4.15 & 0.761 \\
\hline High interest rate & 397 & 2 & 5 & 4.09 & 0.823 \\
\hline High transport cost & 396 & 1 & 5 & 4.05 & 0.743 \\
\hline Lack of entrepreneurial skills & 397 & 2 & 5 & 3.98 & 0.633 \\
\hline Lack of support network & 397 & 2 & 5 & 3.64 & 1.058 \\
\hline Lack of market opportunities & 397 & 1 & 5 & 3.29 & 1.186 \\
\hline Lack of business experience & 397 & 1 & 5 & 3.14 & 1.117 \\
\hline High cost of electricity & 396 & 1 & 5 & 3.01 & 1.114 \\
\hline Corruption based on sex & 397 & 1 & 5 & 2.96 & 1.030 \\
\hline Inability to obtain public tender & 397 & 1 & 5 & 2.91 & 1.089 \\
\hline High communication cost & 395 & 1 & 5 & 2.15 & 0.836 \\
\hline Access to government service & 397 & 1 & 5 & 2.01 & 0.638 \\
\hline Business registration & 397 & 1 & 5 & 1.90 & 0.650 \\
\hline
\end{tabular}

Out of 397 respondents, a strong mean value of 4.26 and a standard deviation of 0.608 were obtained for statement: "lack of collateral to obtain loan". Because of stiff regulations in Rwanda, women are unable to own property, leaving them vulnerable to issues of collateral. Lack of funding opportunities has also been found in studies [4] to thwart women entrepreneurs' business ambitions. A mean value of 4.18 with a standard deviation of 0.747 was obtained for the statement "high taxes". A study conducted by the [33] reported that in many parts of Africa and Asia, respondents complained of high tax rates. To give a general idea of the range of responses, in Rwanda $44.66 \%$ of respondents complained of high tax rates; in Burundi, 36.11\%; Tanzania 36.68\%; Kenya 68.25\%; SA 18.57\%; China $36.8 \%$, and Vietnam $1.85 \%$. The lack of information technology skills and access (e.g., the internet) statement achieved a mean value score of 4.15 , with a standard deviation of 0.761 . Many of these entrepreneurs do not have the ability to use computers. However, it is encouraging that the women entrepreneurs are certainly capable of using cell phones, another form of technology that facilitates the running of their business [32].

The mean value for responses to the "high interest rate" statement was 4.09 , with a standard deviation of 0.823 . The implication of this might be that women will balk at starting a business for fear of taking a loan which they may not be able to repay because of the high interest rate. Laetitia et al. [5], found that the high interest rates of commercial banks and micro-financers are some of the challenges faced by women entrepreneurs in Kigali. By way of contrast, [44] report that South African entrepreneurs are enjoying a flexible interest rate of about $12.9 \%$, which entrepreneurs take advantage of to move their businesses forward. The mean value for responses regarding the "high cost of transport" as a challenge facing women entrepreneurs was 4.05 with a standard deviation of 0.743 . This is an indication that transport is a barrier to the growth and development of women entrepreneurs' businesses.

The statement identifying a "lack of entrepreneurial skills" as a challenge facing women entrepreneurs had a mean value of 3.98 and a standard deviation of 0.633 , which was close to the mean. Stevenson and St-Onge [20] found that a lack of entrepreneurship skills impacts on women entrepreneurs' effectiveness and the growth of their business.

The statement that a "lack of management skills is a challenge facing women entrepreneurs in Kigali" had a mean value of 3.96 and a standard deviation of 0.671. Again, [20] also recognised that women entrepreneurs lack the management skills to really promote their businesses, despite the 
great socio-economic role they play. The statement that "lack of education and training is a challenge facing women entrepreneurs in Kigali" registered a mean value of 3.82. Respondents thus tended to agree that lack of education and training is a challenge facing women entrepreneurs in Kigali. Lose and Tengeh [27] believe that success in business relies on training, education and experience. The statement which suggested that the lack of a support network was a challenge facing women entrepreneurs in Kigali obtained a mean value of 3.64, slightly above the neutral mean of 3 . This implies that respondents largely agreed with the statement. The standard deviation of 1.058, though, showed that respondents' opinions were divided on this issue. Thébaud and Sharkey [45] remark that being part of a network helps women entrepreneurs to conduct their business, especially with men entrepreneurs, which enhances the prospects for business growth.

According to Table 2, mean values of 3.64 to 4.26 were considered as major challenges facing women entrepreneurs in Kigali, and mean values of 2.65 to 3.29 were considered minor challenges. Mean values of 2.31 and below were regarded as not indicative of challenges.

\section{Conclusions and Recommendations}

The main research objective was to determine the challenges experienced by women entrepreneurs in Kigali. This study is important because it seeks to identify the challenges to women entrepreneurship in Kigali, by allowing the voice of women entrepreneurs to be heard. The results of the study will also add to the existing body of knowledge on gendered entrepreneurship, serving as reference to researchers with similar research interests in Rwanda and the rest of the world, particularly in developing countries. A quantitative research approach was used to collect and analyse data.

This study has revealed that women entrepreneurs face many challenges in running their businesses in Kigali. These challenges include among others collateral to obtain loans, high taxes, a lack of information technology skills and access, high interest rates, high transport costs, a lack of entrepreneurial skills, a lack of management skills, a lack of education and training, and the lack of a support network are the major challenges women entrepreneurs face in Kigali. Opportunely, all these challenges have solutions. However, it will take time and combined efforts of women entrepreneurs themselves, their families, society, government, stakeholders, and researchers. First, women entrepreneurs in Kigali should seek information regarding the agencies which help women entrepreneurs and approach them to request the support they need; Secondly, they should work together in associations or cooperatives, reducing rent payable as well as taxes, interest rates, and transport costs, and sharing experience and know-how; Thirdly, the training organised to empower women entrepreneurs must be geared to bringing about positive change in their business activities. The Rwanda Chamber of Women Entrepreneurs should collaborate with those offering training programmes to ensure relevance and quality; Fourth, graduates should view entrepreneurship as a career in which they can create employment for themselves and for others, reduce the unemployment rate and contribute to economic growth; Finally, government should enforce laws to eradicate corruption based on sex, place of origin, favouritism and infidelity.

The significance of this important study should not be diluted owing to the use of simple descriptive statistics. Essentially, considering the vital findings and the necessity for continued uptake of Rwanda-based research, future studies can deploy much more extensive designs incorporating complex statistical efforts. For instance it will be nice to know how successful those subjects without formal education are. Literature tells us that illiteracy is an impediment to entrepreneurial advancement. Perhaps a much more sophisticated statistical inquiry may provide clarity as to the whether this commonly held view holds true in Kigali or not.

Author Contributions: In conjunction with Robertson K. Tengeh and Chux Gervase Iwu, Simon Nsengimana designed and performed the study. All the authors have read and approved the final manuscript.

Conflicts of Interest: The authors declare no conflict of interest. 


\section{References}

1. Tsyganova, T.; Shirokova, G. Gender differences in entrepreneurship: Evidence from Global Entrepreneurship Monitor data. Organ. Mark. Emerg. Econ. 2010, 1, 120-141.

2. Rodríguez, G.P.; Fuentes, F.M.D.M.; Rodríguez, A.L. Strategic capabilities and performance in women-owned businesses in Mexico. J. Small Bus. Manag. 2014, 52, 541-554. [CrossRef]

3. Global Entrepreneurship Monitor. Global Report. 2011. Available online: http://www.gemconsortium.org (accessed on 27 June 2017).

4. Nxopo, Z.; Iwu, C.G. The unique obstacles of female entrepreneurship in the tourism industry in Western Cape, South Africa. Commonw. Youth Dev. 2015, 13, 55-71.

5. Laetitia, M.; Shukla, J.; Luvanda, A. Microfinance and business growth of women small and medium enterprises's in Rwanda. (A case of sellected women and medium enterprises in Kicukiro District). Eur. J. Account. Audit. Financ. Res. 2015, 3, 26-39.

6. Matsoso, M.L.; Iwu, C.G. Women and small scale entrepreneurship. In Introduction to Gender Studies in Eastern and Southern Africa; Sense Publishers: Dordrecht, The Netherlands, 2016; pp. 197-213.

7. Uwantege, K.L.; Mbabazi, P. The impact of women economic empowerment projects on their socio-economic development in Rwanda: The case of agaseke project. Eur. J. Bus. Soc. Sci. 2015, 4, 59-87.

8. International Finance Corporation. Voice of Women Entrepreneurs. 2008. Available online: www.ifc.org/ wps/wcm/connec (accessed on 7 September 2016).

9. Vis, C. Educating Women Entrepreneurs in Kigali, Rwanda. Master's Thesis, University of Amsterdam, Amsterdam, The Netherlands, 2012.

10. Coldham, N.P. Empower Rwandan Women Entrepreneurs: The Gendered Enterprises of Nation-Building. Master's Thesis, Royal Roads University, Victoria, BC, Canada, 2013.

11. Schumpeter, J. Theory of Economic Development: An Inquiry into Profits, Capital Credit, Interest and the Business Cycle; Harvard University Press: Cambridge, MA, USA, 1934.

12. Malhan, A.; Malhan, I. Difficulties and Challenges Faced by Women Entrepreneurs in Gurgaon. Available online: http:/ $/$ www.google.com $/$ url? sa $=t \& r c t=j \& q=\& e s r c=s \&$ source=web\&cd=1\&ved= OahUKEwi9s6K18LnVAhWBULwKHZhnCqsQFggnMAA\&url=http\%3A\%2F\%2Fwww.researchpublish. com\%2Fdownload.php\%3Ffile\%3DDifficulties\%2520and\%2520Challenges \%2520Faced $\% 2520$ By $\%$ 2520Women-1331.pdf\%26act\%3Dbook\&usg=AFQjCNGguxiWDn7qCLtzF2mmuOLPbeXW1Q (accessed on 7 September 2006).

13. Galindo, M.; Guzman, J.; Ribeiro, D. Entrepreneurship and Business: A Regional Perspective; Springer: Heidelberg, Germany, 2009.

14. Begum, R. Determining entrepreneurial success status of women entrepreneurs. J. Bus. Stud. 2003, xxiv, 127-136.

15. Anon, N.D. Culture of Rwanda-History, People, Traditions, Women, Beliefs, Food. Available online: http:/ / www.everyculture.com/No-Sa/Rwanda.html (accessed on 2 October 2016).

16. Fellman, A.C. Focus on Rwanda: A conference on gender research and activist. In Proceedings of the 2011 Conference of the Kigali Institute of Education, Kigali, Rwanda, 11-12 March 2011; pp. 23-24.

17. National Institute of Statistics of Rwanda (NISR). Access to Finance. 2012. Available online: http:/ / www.statistics. gov.rw / publication/access-finance-gender-statistics-publication-vol-2-2012 (accessed on 20 August 2016).

18. Vossenberg, S. Women Entrepreneurship Promotion in Developing Countries: What Explains the Gender Gap in Entrepreneurship and How to Close It; Maastricht School of Management: Maastricht, The Netherlands, 2013.

19. Cutura, J. Voices of Women Entrepreneurs in Rwanda; International Finance Corporation: Washington, DC, USA, 2008.

20. Stevenson, L.; St-Onge, A. Assessment of Environment for the Development of Women's Entrepreneurship in Cameroon, Mali, Nigeria, Rwanda and Senegal; International Labour Office: Geneva, Switzerland, 2011.

21. Wijeyeratnam, I.; Perera, T. Barriers to women's entrepreneurship: SME sector in Sri Lanka. Sri Lankan J. Manag. 2013, 18, 51-81.

22. Zhu, L.; Chu, H.M. Motivations, success factors and problems encountered by Chinese women entrepreneurs: A factor analysis. Int. Rev. Bus. Res. Pap. 2010, 6, 164-180.

23. World Bank. Rwanda Country Profile. 2011. Available online: http://www.enterprisesurveys.org (accessed on 22 August 2016). 
24. Choto, P.; Tengeh, R.K.; Iwu, C.G. Daring to survive or to grow? The growth aspirations and challenges of survivalist entrepreneurs in South Africa. Environ. Econ. 2014, 5, 93-101.

25. Iwu, C.G.; Nxopo, Z. Determining the specific support services required by female entrepreneurs in the South African tourism industry. Afr. J. Hosp. Tour. Leis. 2014, 4, 1-13.

26. Chinomona, E.; Maziriri, E.T. Women in action: Challenges facing women entrepreneurs in the Gauteng Province of South Africa. Int. Bus. Econ. Res. J. 2015, 14, 835-850. [CrossRef]

27. Lose, T.; Tengeh, R.K. The sustainability and challenges of business incubators in the Western Cape Province, South Africa. Sustainability 2015, 7, 14344-14357. [CrossRef]

28. Kelley, D.J.; Brush, C.G.; Greene, P.G.; Litovsky, Y. Global Entrepreneurship Monitor (GEM); 2010 Report: Women Entrepreneurs Worldwide; Global Entrepreneurship Monitor: Babson, MA, USA, 2011.

29. United Nations. Empowering Women Entrepreneurs through Information and Communications Technologies; United Nations: Geneva, Switzerland, 2014.

30. Osoro, K.; Mokoro, A.; Nyamongo, D.; Areba, J. Constraints facing women entrepreneurs in Kenya: A case study of micro and small enterprises in Kisii County. IOSR J. Hum. Soc. Sci. 2013, 16, 116-124.

31. Siddiqui, A.B. Problems encountered by women entrepreneurs in India. Int. J. Appl. Res. Stud. 2012, 1, 1-11.

32. World Bank. The Republic of Rwanda Investment Climate Assessment: Strategy for Sustained Employment and Export Growth; World Bank: Geneva, Switzerland, 2009.

33. Global Press Institute. Sex Corruption Grows as Barrier to Employment for Women in Rwanda. 2012. Available online: http:/ / www.peacewomen.org/.../rwanda-sex-corruption-grows-barrier-employmentwomen (accessed on 31 January 2017).

34. Africa Development Bank Group. Rwanda Energy Sector Review and Action Plan; Africa Development Bank Group: Tunis, Tunisia, 2013.

35. Sukamolson, S. Fundamentals of Quantitative Research. Ph.D. Thesis, Chulalongkorn University, Bangkok, Thailand, 2010.

36. Maree, K. First Steps in Research, 1st ed.; Van Schaik: Pretoria, South Africa, 2007.

37. Rukundo, J.B. Understanding informal sector employment in Rwanda. Int. Rev. Res. Emerg. Mark. Glob. Econ. 2015, 1, 295-309.

38. Saunders, M.; Lewis, P.; Thornhill, A. Research Methods for Business Students, 5th ed.; Pearson: London, UK, 2009.

39. Raosoft. Raosoft Sample Size Calculator. 2004. Available online: http://www.raosoft.com/samplesize.html (accessed on 24 June 2016).

40. Denscombe, M. The Good Research Guide for Small-Scale Social Research Projects, 3rd ed.; Open University Press: New York, NY, USA, 2007.

41. Rwanda. Child Labour, Youth Workers. 2016. Available online: http://www.mywage.org/rwanda/home/ labour-law / fair...work/minors-and-youth (accessed on 28 December 2016).

42. Thanasegaran, G. Reliability and validity issues in research. Integr. Dissem. 2009, 4, 35-40.

43. Global Entrepreneurship Monitor. Is South Africa Heading for an Economic Meltdown; South African Report; The University of Cape Town Development Unit for New: Cape Town, South Africa, 2015.

44. Kganyago, L.; Kazemi, M. South Africa Interest Rate 1998-2016|Data |Chart |Calendar | Forecast. 2016. Available online: http://www.tradingeconomics.com/south-africa/interest-rate (accessed on 13 October 2016).

45. Thébaud, S.; Sharkey, A. Unequal Hard Times: The Influence of the Great Recession on Gender Bias in Entrepreneurial Investment; University of California: La Jolla, CA, USA, 2014.

(C) 2017 by the authors. Licensee MDPI, Basel, Switzerland. This article is an open access article distributed under the terms and conditions of the Creative Commons Attribution (CC BY) license (http:// creativecommons.org/licenses/by/4.0/). 